\title{
Ostra niedomykalność mitralna w przebiegu zawału serca powikłanego pęknięciem mięśnia brodawkowatego
}

\author{
Acute mitral regurgitation during myocardial infarction complicated \\ by papillary muscle rupture
}

\author{
Agnieszka Woronowicz-Chróściel ${ }^{1}$, Katarzyna Starzyk ${ }^{1}$, \\ Zbigniew Starzyk², Beata Wożakowska-Kapłon ${ }^{1,3}$ \\ ${ }^{1}$ I Klinika Kardiologii i Elektroterapii Świętokrzyskiego Centrum Kardiologii w Kielcach \\ ${ }^{2}$ Klinika Kardiochirurgii Wojewódzkiego Szpitala Zespolonego w Kielcach \\ ${ }^{3}$ Wydział Lekarski Nauk o Zdrowiu Uniwersytetu Jana Kochanowskiego w Kielcach
}

\section{Streszczenie}

W pracy zaprezentowano przypadek 59-letniego pacjenta z ostrą, ciężką niedomykalnością zastawki mitralnej, wynikającą z pęknięcia mięśnia brodawkowatego w przebiegu zawału serca bez uniesienia odcinka ST. Objawy niewydolności serca pojawiły się w podostrej fazie zawału serca, przypadającej na 7. dobę po pierwotnej PCl. Dzięki szybkiemu rozpoznaniu, potwierdzonemu w badaniu echokardiograficznym, zastosowano intensywną farmakoterapię oraz wykonano kardiochirurgiczną wymianę zastawki mitralnej.

Słowa kluczowe: zawał serca, pęknięcie mięśnia brodawkowatego, niedomykalność zastawki mitralnej

Folia Cardiologica 2016; 11, 4: 341-345

\section{Wstęp}

W zawale serca (MI, myocardial infarction), leczonym z zastosowaniem nowoczesnych metod, w większości przypadków obserwuje się szybką poprawę czynności lewej komory serca. Nieoczekiwane pogorszenie się stanu klinicznego pacjenta, z cechami zaburzeń hemodynamicznych, powinno skłonić do ponownej oceny klinicznej. Należy powtórzyć też badanie echokardiograficzne i poszukiwać przyczyn postępującej dysfunkcji lewej komory. Mechaniczne powikłania zawału serca występują obecnie u 0,5-5\% pacjentów [1]. Wynikają one z objęcia martwicą i istotnym niedokrwieniem znacznego obszaru ściany lewej komory serca lub mięśni brodawkowatych. Zalicza się do nich pęknięcie wolnej ściany lewej komory lub przegrody międzykomorowej oraz ostrą niedomykalność zastawki mitralnej. Wada serca może się rozwinąć w fazie podostrej zawału wskutek rozstrzeni lewej komory, nagłego pęknięcia mięśnia brodawkowatego lub struny ścięgnistej [2, 3]. Przedłużoną obserwację pacjentów zaleca się w przypadku występowania czynników ryzyka powikłań mechanicznych, takich jak: zaawansowany wiek chorego, objawy ostrej niewydolności serca w II-IV klasie według Killipa, obecność choroby trójnaczyniowej, lokalizacja zawału w obrębie ściany przedniej, długi czas trwania niedokrwienia (od pojawienia się objawów do przezskórnej angioplastyki wieńcowej [PCl, percutaneous coronary intervention]) oraz przepływ w tętnicy wieńcowej, po PCl określany jako mniejszy niż TIMI 3 (według skali Thrombolysis In Myocardial Infarction) [3]. W ostrej fazie zawału mogą wystąpić także powikłania elektryczne, takie jak: arytmie komorowe (występujące nawet u ponad 92\% pacjentów ze świeżym zawałem), nadkomorowe zaburzenia

Adres do korespondencji: lek. Agnieszka Woronowicz-Chróściel, I Klinika Kardiologii i Elektroterapii, Świętokrzyskie Centrum Kardiologii,

ul. Grunwaldzka 45, 25-736 Kielce, e-mail: agawor82@wp.pl 


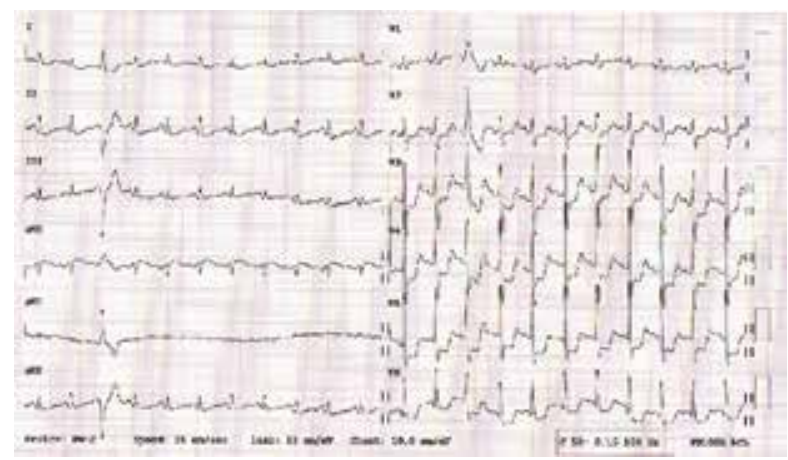

Rycina 1. Tachykardia zatokowa 135 /min, pojedyncze pobudzenia komorowe, obniżenie odcinka ST w odprowadzeniach V4-V6

rytmu (obserwowane u blisko 50\% chorych) oraz zaburzenia przewodnictwa przedsionkowo-komorowego (20-35\%) [4].

\section{Opis przypadku}

Chory w wieku 59 lat, dotychczas nieleczony przewlekle, został przyjęty do Kliniki Kardiologii w stanie ciężkim, z powodu narastającej od kilku dni duszności. W badaniu elektrokardiograficznym stwierdzono tachykardię zatokową 136/minutę, obniżenie odcinka ST w odprowadzeniach V4-V6 oraz pojedynczą ekstrasystolię komorową (ryc. 1). W badaniach laboratoryjnych przy przyjęciu wykazano istotne podwyższenie stężenia troponiny, z charakterystyczną dla zawału serca dynamiką zmian: 779,9-1206 ng/l (N 0,0-3,0). Równocześnie aktywność frakcji mięśniowej kinazy kreatynowej (CK-MB) wynosiła od 12 do $24 \mathrm{U} / \mathrm{L}$ (norma: 0-39), przy stężeniu kinazy fosfokreatynowej (CPK, creatine phosphokinase) od 332 do $717 \mathrm{U} / \mathrm{L}$ (norma: 60-390). W badaniu echokardiograficznym przy przyjęciu stwierdzono hipokinezę ściany bocznej i dolno- -bocznej lewej komory serca, przy łagodnie obniżonej całkowitej kurczliwości lewej komory [frakcja wyrzutowa (EF, ejection fraction) 40\%] oraz umiarkowaną wtórną niedomykalność zastawki mitralnej (typ IIlb według Carpentiera). W wykonanej w trybie pilnym koronarografii wykazano krytyczne zwężenie w środkowym segmencie gałęzi okalającej lewej tętnicy wieńcowej oraz dwie nieistotne hemodynamicznie zmiany w segmencie środkowym dominującej prawej tętnicy wieńcowej (zwężenie światła naczynia do około 40\%). Jednoczasowo wykonano pierwotną angioplastykę wieńcowa tętnicy okalającej, implantując stent powlekany lekiem antyproliferacyjnym (ewerolimusem) i uzyskując prawidłowy przepływ w tętnicy (stopień TIMI 3) (ryc. 2). Pacjent nadal zgłaszał duszność, a jego stan ogólny pozostawał w dalszym ciągu niestabilny. W RTG klatki piersiowej stwierdzono objawy zastoju w krążeniu płucnym oraz zmiany miąższowe położone w środkowym polu płuca prawego, mogące odpowiadać zmianom zapalnym (ryc. 3). Z uwagi na gorączkę i podwyższone stężenie parametrów zapalnych, w tym stężenie białka C-reaktywnego (CRP, C-reactive protein) 148,59 mg/l (norma: 0,10-5,00), rozpoznano zapalenie płuc i włączono antybiotykoterapię empiryczną oraz zastosowano leczenie kompensujące układ krążenia (diuretyk pętlowy, inhibitor konwertazy angiotensyny, beta-adrenolityk, antagonistę receptorów mineralokortykoidowych). W wyniku farmakoterapii uzyskano stopniową poprawę i stabilizację stanu pacjenta, niemniej utrzymano obserwację w warunkach sali intensywnego nadzoru kardiologicznego (sala „R”).

W 7. dobie hospitalizacji nastąpiło gwałtowne pogorszenie stanu klinicznego chorego z silną dusznością spoczynkową. W badaniu przedmiotowym stwierdzono nieobecny wcześniej głośny szmer skurczowy o maksymalnym nasileniu na koniuszku oraz cechy zastoju w krążeniu płucnym. W trybie pilnym wykonano badanie echokardiograficzne

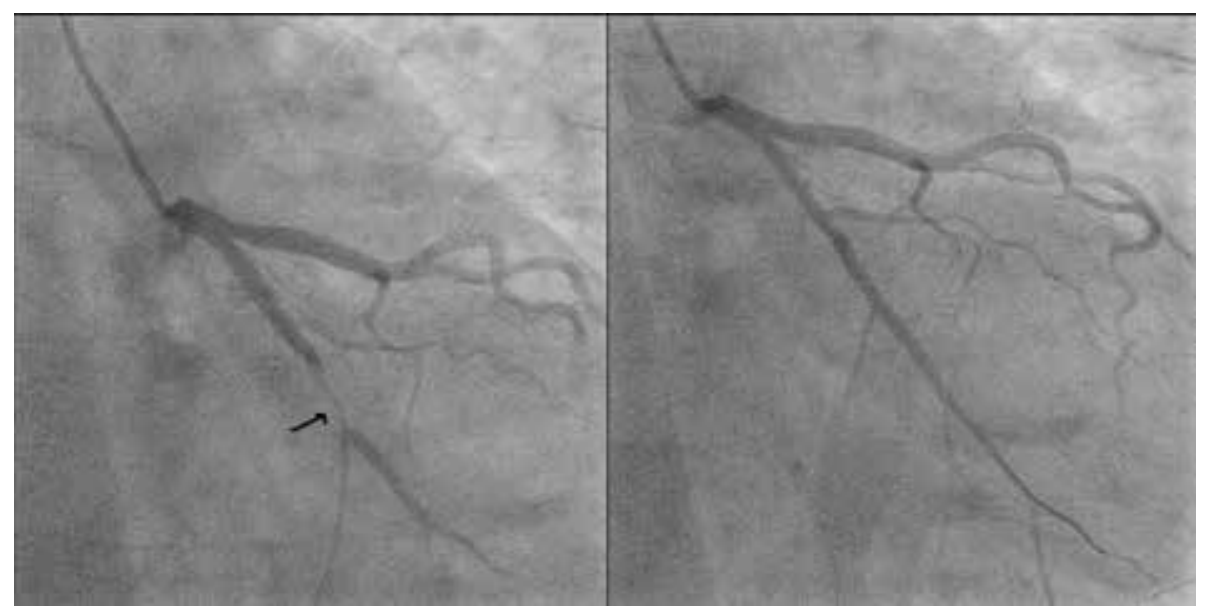

Rycina 2. Obraz tętnic wieńcowych w koronarografii: istotne zwężenie tętnicy okalającej w segmencie środkowym przed i po zabiegu angioplastyki z implantacją stentu powlekanego lekiem antyproliferacyjnym 


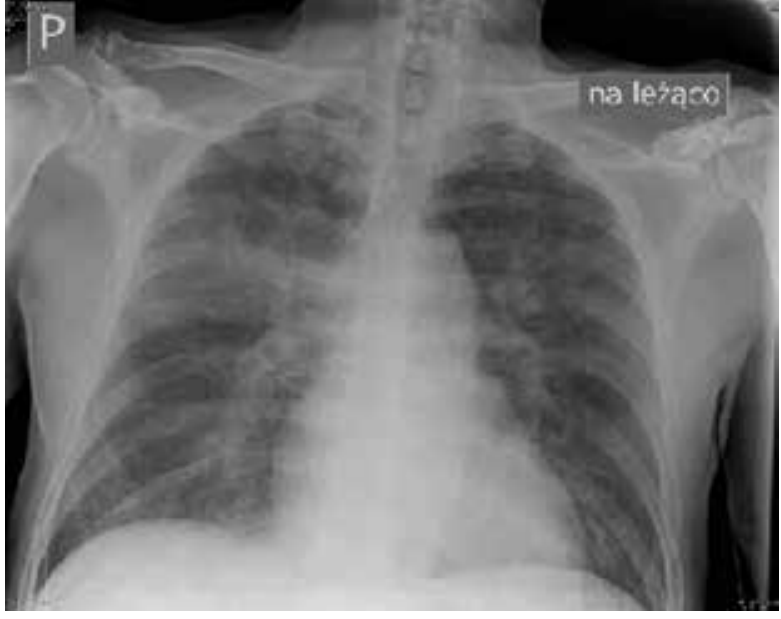

Rycina 3. Rentgenogram klatki piersiowej: zastój w krążeniu płucnym oraz zmiany miąższowe położone w środkowym polu płuca prawego, mogące odpowiadać zmianom zapalnym
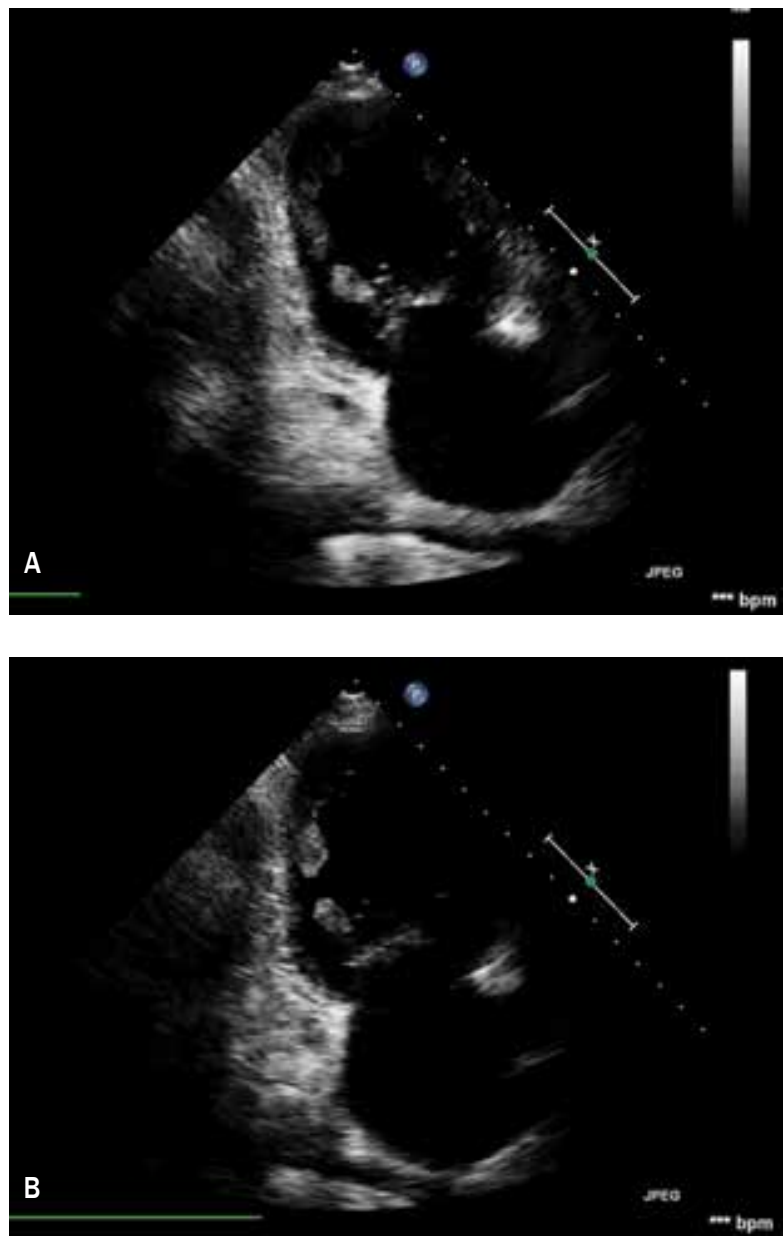

Rycina 4 A, B. Projekcja koniuszkowa dwujamowa: zerwana część głowy mięśnia brodawkowatego tylno-przyśrodkowego

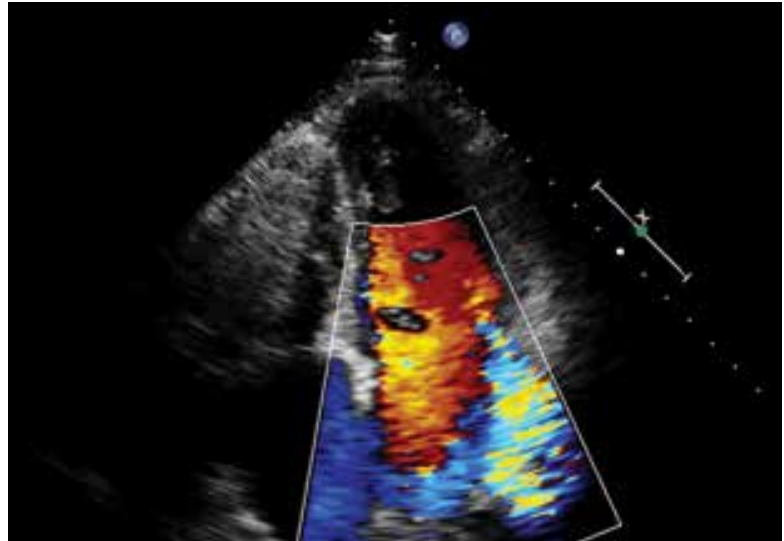

Rycina 5. Projekcja koniuszkowa czterojamowa - kolorowy Doppler: istotna niedomykalność zastawki mitralnej

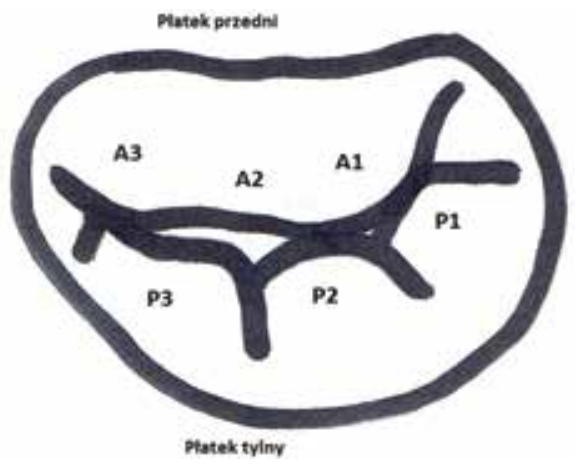

Rycina 6. Schemat badania echokardiograficznego - projekcja przymostkowa w osi krótkiej na poziomie zastawki mitralnej: wypadanie segmentów A2 i A3 płatka przedniego zastawki mitralnej

przezklatkowe, stwierdzając istotną hemodynamicznie niedomykalność zastawki mitralnej [efektywne pole ujścia fali zwrotnej (ERO, effective regurgitant orifice) $1,4 \mathrm{~cm}^{2}$; obj. $152 \mathrm{ml}$, spowodowaną zerwaniem i balotowaniem w świetle lewej komory części głowy mięśnia brodawkowatego tylno-przyśrodkowego (połączonego strunami ścięgnistymi głównie z płatkiem przednim) oraz z wypadaniem tego płatka do lewego przedsionka (ryc. 4-6). Oszacowane, na podstawie prędkości fali zwrotnej przez zastawkę trójdzielną, ciśnienie skurczowe w tętnicy płucnej wynosiło około $95 \mathrm{~mm} \mathrm{Hg}$. Chorego zakwalifikowano do leczenia kardiochirurgicznego w trybie pilnym, zintensyfikowano farmakoterapię, uzyskując optymalną stabilizację hemodynamiczną. Pacjent został zoperowany w krążeniu pozaustrojowym, hipotermii ogólnej, z zastosowaniem kardioplegii. Śródoperacyjnie potwierdzono zerwanie jednej z głów mięśnia brodawkowatego tylno-przyśrodkowego 


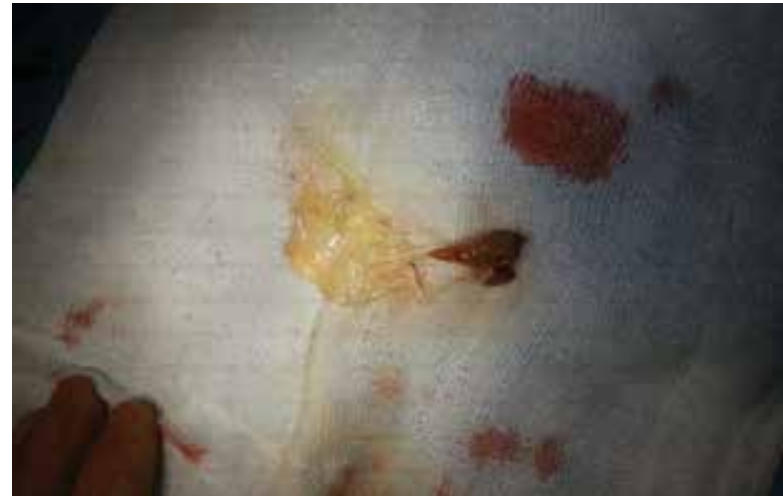

Rycina 7. Przedni płatek zastawki mitralnej z fragmentem aparatu podzastawkowego i urwaną częścią głowy mięśnia brodawkowatego - materiał pooperacyjny

ze strunami skierowanymi do segmentów A2 i A3 płatka przedniego. Usunięto przedni płatek zastawki mitralnej i wszczepiono protezę mechaniczną zastawki mitralnej (St. Jude Medical 29M), z pozostawieniem płatka tylnego i aparatu podzastawkowego (ryc. 7). Dalsze leczenie przebiegało bez powikłań, a w 14. dobie po zabiegu pacjent w dobrym stanie ogólnym został przekazany na oddział rehabilitacji kardiologicznej.

\section{Omówienie}

Ostra niedomykalność mitralna (typu II według klasyfikacji Carpentiera) spowodowana pęknięciem mięśnia brodawkowatego występuje u około $2 \%$ wszystkich chorych leczonych z powodu zawału serca i u około 10\% z tych, u których choroba jest powikłana wstrząsem kardiogennym [3]. Do pęknięcia mięśnia brodawkowatego dochodzi najczęściej pomiędzy 2. a 10. dobą zawału, z lokalizacją w obrębie mięśnia tylno-przyśrodkowego, który często zaopatrywany jest wyłącznie przez jedną tętnicę (gałąź międzykomorową tylną) [5]. Mięsień brodawkowaty przednio-boczny rzadziej podlega uszkodzeniu, bowiem unaczyniony jest zarówno przez tętnicę okalającą, jak i gałąź międzykomorową przednią lewej tętnicy wieńcowej $[5,6]$. W przebiegu ostrej niedomykalności mitralnej dochodzi do dynamicznie narastających objawów niewydolności serca, łącznie z obrzękiem płuc i wstrząsem kardiogennym, opornych na leczenie farmakologiczne, co jest przyczyną niekorzystnego rokowania. Strumień niedomykalności mitralnej powoduje nagłe przeciążenia objętościowe lewego przedsionka i lewej komory serca, co w badaniu przedmiotowym można zaobserwować, stwierdzając nagłe pojawienie się w okolicy koniuszkowej szmeru skurczowego. Szmer ten może być sły- szalny jedynie we wczesnej fazie skurczu, z powodu szybkiego wyrównywania się ciśnień w jamach lewego serca [5, 7]. Podejrzenie ostrego, mechanicznego powikłania zawału serca wysunięte na podstawie oceny klinicznej powinno być potwierdzone w badaniu echokardiograficznym, wykonanym w trybie nagłym. Zwykle w badaniu widoczne jest wypadanie części płatka zastawki mitralnej, do którego przyczepione są nici ścięgniste z fragmentem mięśnia, widocznego w postaci dodatkowego, chaotycznie poruszającego się echa, czasem nawet wpadającego w skurczu do lewego przedsionka. Towarzyszy temu ciężka, wtórna niedomykalność zastawki mitralnej, z falą zwrotną wypełniającą ponad połowę lewego przedsionka [8].

Leczenie farmakologiczne polega na zmniejszaniu obciążenia następczego w celu zmniejszenia objętości fali zwrotnej i zastoju w krążeniu płucnym, z dożylnym zastosowaniem diuretyków, leków naczyniorozszerzających i inotrotropowo dodatnich oraz kontrapulsacji wewnątrzaortalnej (IABP, intra-aortic balloon pump) [9]. Konieczna jest przeprowadzana w trybie nagłym chirurgiczna naprawa lub wymiana zastawki mitralnej, z rozważeniem jednoczasowego wykonania pomostowania aortalno-wieńcowego, jeśli takie postępowanie jest zasadne w konkretnym przypadku. Przedstawiany pacjent był leczony kardiochirurgicznie w trybie nagłym, w kilka godzin po wykonaniu badania echokardiograficznego. U omawianego pacjenta nie zachodziła potrzeba dodatkowej interwencji chirurgicznej w obrębie tętnic wieńcowych, ponieważ tętnica dozawałowa została poszerzona wcześniej metodą PCl i nie stwierdzano innych, istotnych zwężeń w pozostałych naczyniach. Ze względu na stwierdzoną śródoperacyjnie martwicę w obrębie mięśnia brodawkowatego z zerwaniem większej głowy oraz szczątkową drugą głowę mięśnia, nie było technicznych możliwości wykonania plastyki płatka przedniego, dlatego też implantowano sztuczną zastawkę mitralną, pozostawiając natywny płatek tylny z aparatem podzastawkowym, w celu zminimalizowania możliwości wystąpienia w kolejnych miesiącach niekorzystnej przebudowy lewej komory serca.

Ostra niedomykalność mitralna związana z pęknięciem mięśnia brodawkowatego jest obarczona dużym ryzykiem zgonu. W przypadku wystąpienia u pacjenta nowych objawów oraz po stwierdzeniu nieobecnego wcześniej dodatkowego szmeru nad sercem należy wysunąć kliniczne podejrzenie mechanicznego powikłania zawału serca i w trybie nagłym wykonać badanie echokardiograficzne. Właściwe i szybkie rozpoznanie schorzenia, wdrożenie intensywnego leczenia farmakologicznego stabilizującego stan pacjenta oraz kardiochirurgiczna wymiana lub naprawa zastawki mitralnej pozwalają pacjentowi na przeżycie tego, potencjalnie groźnego, powikłania zawału serca. 


\section{Abstract}

We present 59-year-old patient, with acute, severe mitral regurgitation due to papillary muscle rupture in the course of non-ST-elevation myocardial infarction. Signs of heart failure occurred in subacute phase of myocardial infarction, 7 days after primary PCl. Repeated clinical examination, confirmed by immediate echocardiography, led to intensive pharmacological treatment and subsequent urgent surgical valve replacement.

Key words: myocardial infarction, papillary muscle rupture, mitral regurgitation

Folia Cardiologica 2016; 11, 4: 341-345

\section{Piśmiennictwo}

1. Thompson C.R., Buller C.E., Sleeper L.A. i wsp. Cardiogenic shock due to acute severe mitral regurgitation complicating acute myocardial infarction: a report from the SHOCK Trial Registry. Should we use emergently revascularize Occluded Coronaries in cardiogenic shock? J. Am. Coll. Cardiol. 2000; 36: 1104-1109.

2. O'Gara P.T., Kushner F.G., Ascheim D.D. i wsp. 2013 ACCF/AHA Guidelines for the Management of ST-Elevation Myocardial Infarction. A Report of the American College of Cardiology Foundation/American Heart Association Task Force on Practice Guidelines. Circulation 2013; 127: 362-425.

3. Steg G., James S., Atar D. i wsp. Wytyczne ESC dotyczące postępowania w ostrym zawale serca z przetrwałym uniesieniem odcinka ST. Grupa Robocza Europejskiego Towarzystwa Kardiologicznego (ESC) do spraw postępowania w ostrym zawale serca z uniesieniem odcinka ST. Kardiol. Pol. 2012; 70: 256-306.

4. Bloch Thomsen P.E., Jons C., Raatikainen M.J. i wsp. Long-term recording of cardiac arrhythmias with an implantable cardiac monitor in patients with reduced ejection fraction after acute myocardial infarction. Circulation 2010; 122: 1258-1264.

5. Nishimura R.A., Schaff H.V., Shub C. i wsp. Papillary muscle rupture complicating acute myocardial infarction: analysis of 17 patients. Am. J. Cardiol. 1983; 51: 373-377.

6. Mill M.R., Wilcox B.R., Anderson R.H. Surgical Anatomy of the Heart. W: Cohn L.H. Cardiac Surgery in the Adult. Third Edition. Mc Graw Hill Medical, New York 2008: 29-49.

7. Russo A., Suri R.M., Grigioni F. i wsp. Clinical outcome after surgical correction of mitral regurgitation due to papillary muscle rupture. Circulation 2008; 118: 1528-1534.

8. Michałek P., Hoffman P. Częściowe pęknięcie mięśnia brodawkowatego $\mathrm{W}$ ostrym zawale mięśnia sercowego - rozpoznanie przy użyciu echokardiografii przezprzełykowej. Kardiol. Pol. 2006; 64: 637-640.

9. Yoshida S., Sakuma K., Ueda O. Acute mitral regurgitation due to total rupture in anterior papillary muscle after acute myocardial infarction successfully treated by emergency surgery. Jpn. J. Thor. Cardiovasc. Surg. 2003; 51: 208-210. 